\title{
IFITM1 wt Allele
}

National Cancer Institute

\section{Source}

National Cancer Institute. IFITM1 wt Allele. NCI Thesaurus. Code C52041.

Human IFITM1 wild-type allele is located in the vicinity of $11 \mathrm{p} 15.5$ and is approximately 1 $\mathrm{kb}$ in length. This allele, which encodes interferon-induced transmembrane protein 1 protein, plays a role in the inhibition of cell proliferation and regulation of cell adhesion signals. 